O modelo

moderno

do jurista

perfeito

António Manuel Hespanha[1]
Resumo: Partindo da análise da literatura deontológica dirigida aos juristas, procura-se traçar o retrato ideal dos juristas, relacionando-o com o imaginário social acerca da justiça e do direito. Esse modelo dos juristas não representa apenas um ideal do grupo, mas ainda uma norma de comportamento para os juristas e uma referência para a sociedade, que, ao lidar com o grupo dos letrados, é decisivamente influenciada pelo modo como eles próprios se imaginam, imagem que procuram difundir e inculcar nos outros. Subjacentes estão convicções metodológicas acerca do poder conformador dos imaginários e dos discursos.

Palavras-chave: juristas; justiça; imaginários sociais.

The early modern "perfect jurist"

Abstract: Based on the analysis of the deontological literature regarding jurists, the ideal portrait of the jurists is drawn, relating it with the social imaginary about justice and law. This model of jurists is not only an ideal of the group, but also a standard of behavior for jurists and a reference for society which, in dealing with the group of legal letrados, is decisively influenced by the way in which they imagine themselves. Image they seek to spread and inculcate in others. Underlying are methodological convictions about the shaping power of imaginaries and discourses.

Keywords: jurists; justice; social imagery. 


\section{Questões de método}

$\mathrm{G}$ rande parte dos trabalhos de prosopografia de juristas ${ }^{2}$ tem partido de critérios de definição e de compreensão dos universos de indivíduos de que se ocupam baseados nas lógicas de categorização social do historiador, quer estas sejam as do senso comum, quer sejam classificações propostas pelas ciências de nossos dias. Por isso, a identidade do grupo estudado pode não coincidir com a identidade que este tinha constituído para si mesmo (com as respetivas categorias "indígenas" de identificação). Como essas categorias estão ligadas às imagens sobre si mesmo (autorrepresentações), padrões de comportamento, critérios de diferenciação e de oposição grupal, sentimentos de proximidade e de distância e estratégias sociais correspondentes, com aquele erro metodológico quase tudo se perde no que respeita à compreensão da "economia moral" e da "prática social" do grupo estudado.

Tendencialmente, a pretensão do historiador quanto à reconstituição da realidade histórica, livre de qualquer distorção, é ilusória. Mas pelo menos deve-se tentar, a todo custo, reduzir ao mínimo a imposição ao material histórico de categorias anacrônicas, procurando antes contextualizar os "dados" com os imaginários e as categorizações da época. Tal como o antropólogo, o historiador leva, assim, a cabo uma "observação participante", tentando ler os textos (em sentido estrito ou alargado) das fontes como o faria um contemporâneo destes.

No caso da prosopografia, essa "leitura profunda" (Medick, 1984, p. 295-319) consiste em interpretar os "fatos brutos" em função das autorrepresentações (da "economia moral") do grupo considerado, integrando sua ideografia em sua prosopografia. Só esse procedimento pode esclarecer as avaliações que então se fez das situações, os desafios enfrentados, as estratégias projetadas, o balanço dos resultados obtidos. Trata-se, enfim, de substituir a contextualização "sociológica", clássica nos estudos prosopográficos dos comportamentos, por sua contextualização ideográfica.

Para designar essas representações de si mesmos, que enquadram percepções do mundo e influenciam comportamentos, a historiografia (e a teoria social) contemporânea tem usado conceitos como "economia moral" (E. P. Thompson, 1991; ver Götz, 2015, p. 147-162), "habitus" (P. Bourdieu, 1972 e 1980) ou "persona" (H. Paul, 2014, p. 348-371). Para seus criadores, esses conceitos tinham contornos próprios, por vezes exaustivamente analisados. Neste texto, prescindo desse rigor analítico, fixando-me no que eles têm de comum como metodologia para revelar os impensados, que dirigem a ação em sua utilidade heurística — a suposição

${ }^{2}$ Não existem boas sínteses de história social dos juristas nas Idades Média e Moderna. Elementos dispersos podem ser colhidos nas sínteses de história do direito. Obra clássica de biografia coletiva, capaz de ajudar a traçar modelos, é: Diplovataccio (1511 [ed. cont., 1968]), Sarti (1888), Savigny (1831), Lange (1997) e Lange e Kriechbaum (2007). Para Portugal (e Brasil), além de Diogo Barbosa Machado, Bibliotheca Lusitana [...], Aragão (1781), Subtil (2010) e Camarinhas (no prelo). Entre os ensaios de interpretação social e política, destaco: Sbriccoli (1969), Horn (1978), Ranieri (1985), Bouwsma, William J. Lawyers and Early Modern Culture. In: PREST, William (org.). Lawyers in Early Modem Europe and América, op. cit., e Kelley (1988). Para Portugal, o estudo mais importante é o de Barbas Homem (2003). 
de que existem impensados coletivos, gerados pelas condições da prática, que condicionam a perceção e dirigem a ação de certos grupos de agentes e de que esses impensados podem ser reconstituídos a partir de uma hermenêutica dos discursos e das atitudes comuns.

Para além disso, embora a cultura específica de cada grupo constitua uma cultura "local", pouco suscetível de ser difundida ou exportada (i.e., de ser aceita por outros grupos), certos grupos caracterizam-se por um enorme poder de disseminação de imagens de si mesmos e da sociedade. Ou seja, por sua capacidade de constituir reservas de tópicos a que outros grupos irão recorrer para constituir sua própria visão do mundo. Nesses casos, o estudo do imaginário "indígena-local" pode também fornecer elementos heurísticos para a compreensão de imaginários mais difusos e partilhados sobre a sociedade e o poder.

A reconstrução dessas autorrepresentações dos grupos pode fazer-se, nomeadamente, pelos discursos que esses grupos produzem sobre si próprios e sua atividade. Dentre esses salientam-se tanto a literatura explicitamente deontológica quanto as descrições das qualidades e dos defeitos que frequentemente ocorrem em textos de outra natureza. ${ }^{3}$

Um dos gêneros da literatura jurídica durante a época moderna é o dos tratados sobre as exigências do saber jurídico e sobre os requisitos (físicos, psíquicos e morais) daqueles que o cultivavam específico. Exemplos dela são tratados que levam títulos como perfectus judex, ${ }^{4}$ ou perfectus doctor, ${ }^{5}$ entre os quais os que são usados neste texto.

Ao instituir um modelo de comportamento, essas obras instituem também uma taxinomia social que relaciona os juristas com outros grupos:

(i) distinguindo-os;

(ii) aproximando-os ou afastando-os;

(iii) hierarquizando-os em função dos outros grupos sociais.

Para além disso, os elementos de distinção e de hierarquização funcionam também no interior do próprio grupo:

(i) criando aí uma identidade, uma economia moral e um código de comportamento;

(ii) introduzindo aí subdistinções e sub-hierarquias (doctor, relator, iudex, advocatus).

Em seguida, tentaremos levantar a lógica interna do modelo espiritual e comportamental que corresponderia à particular natureza dos juristas.

${ }^{3}$ Acerca desses discursos, põem-se todos os problemas metodológicos comuns ao estudo de textos: sentidos pretendidos pelo autor, sentidos construídos pelos leitores; contextos de produção, contextos de leitura; contextos e intertextos; dinamismo do sentido nas tradições textuais. Ver, por todos, Zyma (1980). Para a literatura jurídica, Ranieri (1982).

${ }^{4}$ Matienzo (1653), Pereira (1636 e 1662), Macedo ([16]43), Velasco (1662), Araújo (1743) e Cunha (1743).

${ }^{5}$ Cf. Kelley (1988) e Barni (1960 [1588]); com um muito maior desenvolvimento, Barbas Homem (2003). 


\section{O conhecimento das coisas divinas e humanas (humanarum atque divinarum rerum notitia)}

No proêmio de seu tratado De iustitia et de iure (Acerca da justiça e do direito) (1556), Domingo de Soto entende dever justificar o fato de, sendo teólogo, se ocupar de temas jurídicos:

Ninguém deve censurar que os teólogos se encarreguem desta tarefa, que parece ser mais própria dos jurisconsultos, já que o direito canônico brotou das entranhas da teologia, tal como o direito civil brotou da ética. Por tanto, ao teólogo pertence ajustar as determinações do direito canônico às normas do Evangelho e ao filósofo acomodar o direito civil aos princípios da filosofia. Pelo qual, Cícero afirma que a doutrina do direito não há-de ter como fonte os editos do pretor, nem as Doze Tábuas, mas antes as próprias entranhas da filosofia. Discutir a razão das leis é mais ignorância do direito que sua ciência. (Soto, 1556, I, qu. 1, a. 1).

Essa justificação decorre de sua opinião de que o direito é uma ordem racional que se apreende sondando a natureza íntima das coisas, sendo, portanto, pueril querer reduzir o saber político a uma descrição da vontade dos governantes (i.e., das leis). Pelo contrário, o saber político (e jurídico) teria de visar a um conhecimento global e mais profundo, que coincidiria, diz Soto, "com as próprias entranhas da filosofia". No saber jurídico do renascimento tardio, o prestígio de Cícero relacionava-se justamente com sua intuição de que, por detrás dos detalhes do direito positivo, existia uma ordem natural do direito, que ele teria tentado descrever em uma sua lendária descrição sistemática de todo o direito civil romano. A ideia de que existiam princípios subjacentes a todas as ordens jurídicas, em qualquer época, seria bastante estranha para um jurista romano da república tardia ou do principado; mas encontra-se em um jurista mais tardio, Ulpiano (falec. c. 230), autor de uma definição famosa dos juristas como sacerdotes iuris, ou seja, como cultores especializados de um saber do direito baseado na hermenêutica da natureza. ${ }^{6}$

De acordo com uma teoria do direito desse tipo, um conhecimento do direito apenas podia ser obtido a partir de três vias: a revelação, uma participação natural na sabedoria que criara a ordem do mundo (descrita como bonitas ou honestas) ou a observação da natureza. Os três elementos estão presentes, de alguma forma, na epistemologia medieval e primomoderna da política e do direito.

${ }^{6}$ Sobre essa particularidade da cultura jurídica europeia, de ter criado um grupo diferenciado de especialistas em direito, ver Schiavone (2005, ch. V e XXII). 


\section{Religio, revelatio}

A revelação era uma dessas fontes. Nela se tinha apoiado a doutrina do direito desde Santo Agostinho. Mas a revelação nem era exaustiva nem pretendera tirar aos homens a autonomia e a liberdade de organização. Além de que a vontade de Deus, revelada pelos livros inspirados, tinha aspectos desconcertantes, manifestando-se em sentidos contraditórios. Assim, contrariando os princípios do Decálogo, Deus mandara matar — v.g., quando ordenou a Abraão o sacrifício de seu filho - , mandara roubar — quando ordenou aos judeus que roubassem os egípcios, no episódio da fuga do Egito (Exod., II, 22; XI, 2/3; XI, 35) —, mandara cometer adultério - quando ordenou a Oseias que se unisse a uma prostituta (Oseias, cap. 3) (cf. Villey, 1968, p. 182). Porém, essas contradições da vontade "conjuntural" de Deus eram resolúveis, se se inserisse essa vontade episódica, conjuntural, livre, absoluta, de Deus em sua vontade permanente, estrutural, ordenada, racional. Isso correspondia, afinal, a sujeitar a "revelação" à averiguação racional (embora arriscada) acerca das "razões" de Deus, consistentes com as finalidades da Criação. Por isso é que se afirma que "a lei de Deus não está na sua vontade, mas antes no seu entendimento, que é o que manda ou proíbe" (Soto, 1556, I, qu. 1, a. 1. 1. I, qu. 1, art. 1).

\section{Gnose, harmonia, bonitas, honestas}

A revelação também podia se fundar nas capacidades intuitivas do homem, em seus poderes para entender a profundidade das coisas - nesse caso, a harmonia das coisas - por meios para-racionais, como propunha a gnose. São Tomás refere-se a isso em sua discussão sobre equidade e justiça (Summa theologica, IIa.IIae, qu. 80, art. 1). O ponto de partida é a declaração de Aristóteles de que a equidade (epieikeia) era uma virtude anexa à justiça. Usando sua peculiar técnica de raciocinar (quaestio, progredindo de um problema particular para questões cada vez mais gerais), São Tomás interroga-se sobre uma questão mais geral acerca da natureza de um tipo de conhecimento que designa por gnome:

Respondo que os hábitos de conhecer são distintos, conforme se baseiam em princípios mais elevados ou menos elevados. Por isso, o conhecimento das coisas especulativas lida com princípios mais elevados do que os das ciências. Essas coisas que estão para lá da ordem dos princípios inferiores ou causas estão evidentemente dependentes da ordem dos princípios mais elevados: por exemplo, se a explicação dos monstros [i.e., criaturas monstruosas, sem a forma característica daquela espécie] está para lá da ordem das forças ativas do sémen, isso quer dizer que ela se situa no nível de princípios mais

75umma theologica, Ila.llae, qu. 51, n. 4, "Se a gnome é uma virtude especial". 
elevados, como a influência dos corpos celestes ou, para além disso, a ordem da Providência divina [...]. No entanto, acontece às vezes que é necessário fazer algumas coisas que estão acima da ordem dos atos comuns [...] e, por isso, neste caso devemos julgar as ações por princípios que estão acima das normas comuns [...]. Para julgar de acordo com estes princípios mais elevados, necessita-se de uma outra virtude judicativa, chamada gnome, a qual requer uma particular perspicácia de julgamento [...].

No fundo, essa perspicácia era o sinal das virtudes que aproximavam o homem da divindade - sua bondade, ou capacidade para conhecer o bem, ${ }^{8}$ e sua honestidade, ou tendência, para ser verdadeiro, para seguir os preceitos da natureza (Summa theologica, IIa. IIae, qual. 145, 2, 4c).

Esse relance sobre as conceções psicológicas implícitas de São Tomás — que confirma o que se disse sobre os distintos níveis da ordem - permite também caraterizar uma forma mais refinada e profunda de conhecimento que possibilitava alcançar níveis superiores e mais escondidos da ordem do mundo e que permitia entender, a partir daí, soluções jurídicas que não podiam ser explicadas pela regra geral.

Da gnose faziam tradicionalmente parte os três saberes (gnósticos) que se ocupavam da harmonia - a aritmética, a geometria e a música - e que constituíam, assim, uma via de acesso, não discursiva, ao sentido da ordem, e também da ordem política. Boécio (480-524), filósofo muito lido durante toda a Idade Média, teorizara essa simpatia entre a harmonia da música e a harmonia da política em seu pequeno tratado Sobre a música (De musica). Já na época a que nos reportamos, a aproximação entre música e política aparece, por exemplo, no texto seguinte:

[...] temos que considerar que, como a viola nas mãos do destro tangedor, assim é a República nas mãos de seu Rei, Príncipe ou Magistrado que a governa. O qual deve primeiro concertar as vontades [...], com tanto tempo e cuidado que os súbditos façam uma bem concertada polícia, vivendo com paz, união e concórdia e com a perfeita caridade que o título e nome de cristão prometem. E se entende que se algum deles desconcerta e se desvia disto, o príncipe lhe deve ir logo à mão, antes que desconcerte os demais e seja causa que perturbe a pública quietude e paz. (Camos, 1592).

D. João, duque de Bragança, um músico que a Revolução de 1640 virá a pôr no trono português, teria sido - segundo seu partidário António de Sousa de Macedo — um bom rei, porque, já antes de ser rei, estudava a política nas notas musicais. Esse mesmo autor coloca significativamente a palavra "harmonia" no título de uma obra política (Armonia política dos documentos divinos com as conveniências do Estado, Haia, 1651). E, alguns anos mais

8"Bonum hominis consistit in coniunctione eius ad Deum", Summa theologica, la.llae, qual. 19, 11 c.; "Impossibile est quod aliquis homo sit bonus, nisi sit bene proportionatus bono communi", Summa theologica, la.llae, qual. 92, 1 ad 3. 
tarde, Sebastião Pacheco Varela escreve uma obra em que se adivinha o futuro político do reino e se dão conselhos de política ao príncipe por meio de números e notas musicais (Numero vocal [...], Lisboa, 1702).

\section{Um conhecimento escalonado da justiça}

Havia, porém, outras vias de aceder ao conhecimento da justiça e do direito. A definição mais famosa do saber jurídico é a dos juristas romanos em um célebre passo do Digesto ("Iurisprudentia est divinarun atque humanarun rerum notitia, iusti atque iniusti scientia", Ulpiano, D., 1, 1, 10, 2). A definição inclui vários níveis de conhecimento (notitia, scientia) relativos aos vários níveis da ordem do mundo (humanarum atque divinarum rerum).

O fato de o conhecimento da ordem se realizar em vários níveis, sucessivamente mais elevados e mais exigentes de capacidades cognitivas, gerava um saber jurídico plural, em que coexistiam diversos pontos de vista, alguns deles fatualmente indecidíveis por se situarem em níveis relativamente herméticos da hermenêutica da ordem do mundo.

A estrutura argumentativa que facilmente se observa na doutrina jurídica medieval e moderna do direito ${ }^{9}$ decorre dessa pluralidade de níveis de sondagem da ordem, cada um deles sugerindo pontos de vista sobre a solução justa, que tinham de ser confrontados entre si. Como alguns desses pontos de vista derivavam da sensibilidade sobrenatural da fé, de intuições sobre aspectos escondidos das coisas, ou da observação de uma natureza irredutivelmente complexa e mutável, o confronto desses pontos de vista nunca podia encerrar a discussão. A jurisprudência era, por natureza, uma tarefa cognitiva irremediavelmente aberta. E, assim, o saber dos juristas tornava-se um saber com regras herméticas e, por isso, algo dificilmente sindicável. Isso viria a ser uma das chaves para seu poder social.

Essa estrutura escalonada do saber dos juristas refletia-se na arquitetura de suas almas.

Juan de Matienzo (1653), que escreveu um trabalho detalhado sobre a deontologia das profissões jurídicas na forma de um diálogo entre um advogado e um juiz (relator), usa a metáfora da árvore para traçar o retrato moral dos juristas e descrever a hierarquia d suas virtudes e seus vícios. Às raízes pertenciam o temor de Deus (III, 6), a ciência (III, 7), a experiência (III, 9 ss.), a autoridade (III, 12) e, como vícios, a desconfiança e a credulidade (III, 13). Do tronco faziam parte a fortaleza e a integridade (III, 13 ss.). Na medula desse tronco, a verdade (honestidade), a fidelidade e o segredo. Sua casca era a paciência (III, 38) e a ponderação (III, 39). À copa, que abrigava o todo, pertenciam a prudência e a ponderação, que vêm da idade (III, 58). Suas flores, ou ornatos, ${ }^{10}$ eram a fiabilidade (commitas), a afabilidade e a eloquência (III, 57). Os frutos - o decisivo - eram a justiça, quer consistisse na aplicação do direito estrito

${ }^{9}$ Por todos, ver Viehweg (1953) e Vallauri (1967)

10Porém, estavam na origem dos frutos, da mesma forma que a eloquência preparava a aceitação da solução justa. 
(III, 62), na equidade (III, 53), no perdão ou na misericórdia (III, 66). A metáfora exprime a ordem escalonada das virtudes que proporcionavam ou reforçavam as capacidades intelectivas necessárias a um jurista, indo desde a proximidade com Deus às disposições intelectuais puramente terrenas e auridas da prática da vida quotidiana, como a ponderação.

Assim, o modelo anímico de um jurista era bastante complexo. Ele abrangia dons espirituais, hábitos intelectuais e características físicas, como o gênero, a naturalidade ou mesmo a morfologia e as disposições do corpo. Consultando tratados da época sobre a deontologia dos juristas, podemos surpreender o imaginário da época sobre a natureza do jurisperito. É o que se fará nos parágrafos seguintes, em que se compendiam as opiniões de vários tratadistas sobre a deontologia jurídica. ${ }^{11}$

\section{Virtudes, qualidades e vícios}

Algumas das qualidades dos juristas diziam respeito a características naturais.

\section{Um corpo perfeito}

Comecemos pelo nível mais externo: a compleição do corpo. Não tão externo como isso, pois, como vamos ver, a compleição física podia revelar a disposição interior. Aqui, as regras provinham da fisionomia ("ciência pela qual se conhecem as compleições boas ou más, salvo o livre-arbítrio, que nos permite contrariar a natureza"), ${ }^{12}$ embora alguma tradição ligada à compleição de juristas famosos pudesse ter influído.

Por temperamento, os juristas deviam ser sanguíneos, "quentes" e "úmidos", tudo isso apontando para um biótipo caracterizado por um feitio calmo e judicioso (Della Porta, 1586, V , 2). O corpo não devia ter marca ou defeito, refletindo a perfeição da alma, de acordo com uma ideia de semelhança entre essência e aparência, que subjaz à fisionomia ("os vícios da alma penetram na alma, e a má aparência do corpo é um sintoma de uma alma desequilibrada" [Macedo, [16]43, cap. 5, 12; Della Porta, 1586, I, 2]). Por isso, não eram admitidos no grupo dos advogados letrados os mudos, os surdos, os cegos ou o louco permanente (Gil, 1613, cap. 2, n. 1). Além disso, o corpo devia ser mediano, bem-equilibrado e bem-proporcionado (Della Porta, 1586, II e IV). Também o fato de os juristas deverem ser publicamente visíveis, em lugares marcados pela dignidade e pelo decoro do poder, dava argumentos no mesmo sentido da perfeição e proporção do corpo (Macedo, [16]43, cap. 13). A compleição

"Ver, com muita informação, Barbas Homem (2003, p. 325).

${ }^{12}$ Macedo ([16]43, c. 5, n. 14). Macedo cita o fisionomista Giambattista della Porta (1535-1615, De humana physiognomonia libri IIII, Vici Aequensis, Josephum Cacchium 1586), bem como médicos - Galeno, Jerónimo de Campos e Gaspar Cardoso. Sobre a fisionomia, Baroja (1993). Sobre seu uso na avaliação das pessoas para efeitos jurídicos, ver Schmölders (1996). 
física não devia ser avantajada, mas antes tender para a pequenez. A magreza seria melhor do que a gordura. A pele devia ser branca, tendendo para o rosado. Os cabelos, claros, lisos e conservados com a idade. A cabeça devia ser pequena e redonda. A testa, alta e sem cabelos na parte superior. As sobrancelhas, leves e claras. Os olhos, pequenos, negros e brilhantes (Della Porta, 1586, III). Orelhas pequenas. Nariz direito e levantado. Boca e lábios pequenos. Dentes irregulares. Língua pequena. Uma voz firme, clara e decidida. Parco no rir e no chorar. Queixo pequeno, saliente e algo carnudo. Rosto gracioso e um pouco rosado. Pescoço grosso e curto. Ombros delicados e baixos. Costas esbeltas. Barriga pequena. Peito estreito. Braços pequenos, delicados e lânguidos. Mãos esbeltas. Dedos fletidos para cima. Pés bem-formados.

De todos os detalhes físicos descritos, os mais importantes eram os que se relacionassem com aqueles órgãos que, por sua centralidade simbólica, melhor exprimiam as qualidades interiores aqui centrais ("a cabeça e os lugares mais vizinhos, os olhos, que segundo Galeno fazem parte do cérebro, e o peito, que é a sede do coração; depois as pernas e os pés; finalmente o ventre" [Macedo, [16]43, cap. 13, n. 17]).

Outro autor um pouco anterior (Matienzo, 1653, p. 108) traçava uma imagem física menos detalhada. A face seria juvenil e aberta, pois o saber jurídico manteria a juventude, ao passo que a face (e o coração, que com ela mantinha uma relação de simpatia) deveria ser veraz, nada devendo esconder.

Em suma, cada detalhe corporal contribui com um elemento para uma hermenêutica do corpo, possibilitando o "silogismo fisionômico", descrito por Giambattista della Porta para deduzir características temperamentais dos sinais do corpo. A ortodoxia teológica, que valorizava o livre-arbítrio, obrigaria a matizar o determinismo biológico a que a ideia de silogismo induzia. Mas permanecia a ideia de que compleição e comportamento eram sinais prováveis da forma da alma.

Independentemente dos detalhes pitorescos, o que interessa é realçar como isso remete ao caráter natural das disposições físicas, intelectuais e morais que caraterizavam um bom jurista.

Esse biótipo natural do jurista comportava ainda outros elementos, desde o gênero, a pátria, a família e a idade, até circunstâncias sociais adquiridas, mas que, por sua permanência, se incorporavam na natureza, como a riqueza e as maneiras.

\section{Genus}

O gênero devia ser o masculino, para evitar a mobilidade e a falta de rigor própria das mulheres (como então se dizia, a "inteligência extraordinariamente úmida das mulheres"). Na verdade, as mulheres só no falar pareciam ter um aparente engenho, mas apenas "sobre matérias fáceis e por palavras comuns e presumidas" (Perfectus doctor [...], cit., c. 3). De matérias de 
letras, "nada poderiam dizer, para além de certa latinidade e isto porque esta depende apenas da memória" (Perfectus doctor [...], cit., n. 8). Seu conselho seria "inválido, frágil e mutável" (Perfectus doctor [...], cit., n. 8), embora houvesse mulheres sensatas, como muitas vezes eram as esposas dos juristas, que eles tinham o hábito de consultar para testar a aceitabilidade das soluções pelos leigos na ciência. Finalmente, o próprio caráter prático da prudência, que, "tal como a árvore tende para os frutos", excluiria as mulheres, que, por não poderem exercer cargos civis ou públicos, não tinham podido amadurecer sua prudência, como conhecimento prático (Macedo, Perfectus doctor, c. 5, n. 14; Juan de Matienzo, Dialogus [...], cit., p. 273 ss.).

Uns 150 anos mais tarde, um jurista sensível aos méritos de espírito - Jerónimo da Silva Araújo - matiza esse juízo puramente negativo (Araújo, 1743, cap. 27, p. 127). Mulheres houvera, na Antiguidade e na tradição medieval dos juristas, notáveis por seus dotes para o direito. Uma filha de Acúrsio chegara a ensinar em Bolonha (Perfectus doctor [...], cit., n. 3). Isso mesmo documentaria a observação comum de haver senhoras sábias e prudentes, capazes, pelo menos, de dar boas esposas para os letrados saídos de cidade do Mondego (Perfectus doctor [...], cit., n. 12). Mas, no final, a resolução era a mesma: a honestidade do sexo e a fragilidade do conselho impediriam as mulheres de dar consultas públicas de direito, embora o pudessem fazer em privado, uma vez que capacidade de espírito não faltaria a muitas (Gil, 1613, cap. 2, n. 5).

\section{Pátria e família}

Quanto à pátria, os juristas deviam provir de um lugar de ar temperado. Esse clima nutriria os engenhos elevados e sublimes, "por causa da amenidade e temperança dos lugares, livres de nuvens chuvosas". E daí que os "homens das regiões temperadas antecedam de longe os outros nos costumes do corpo e da alma, na inteligência e na prudência", como ensinara Galeno (Macedo, Perfectus doctor [...], cap. 1). Entre os dois extremos, os homens dos lugares quentes seriam mais sábios do que os dos lugares frios, pois o calor, tal como o vinho, fá-los-ia regressar à juventude, dispensando o adjutório da bebida. Macedo reconhece, naturalmente, que há exceções. Mas a formulação da regra - inspirada nos médicos, mas também na própria história dos juristas europeus, em que o Sul predominara, até então, sobre o Norte - constituía um tópico que podia produzir, automaticamente, hierarquias.

Relativos ao nascimento era ainda o tópico da origem familiar. Mas este, como veremos, muito mais cheio de conteúdos simbólicos suscetíveis de aplicação prática.

A geração, a primeira educação e o exemplo dos progenitores e antepassados eram fatores decisivos na natureza dos juristas. De fato, "a nobreza dá firmeza a todas as artes e presumese que quem descende de geração nobre seja um homem nobre e estudioso da virtude, sendo o contrário também verdade [...]. Isto tanto pela natureza como pelo 
exemplo e imitação" (Macedo, [16]43, cap. 2, n. 3). Daí que os filhos dos doutores juristas, "se bons, devam justamente preferir a outros" (Macedo, Perfectus doctor [...], cap. 1), pois "quem tem os seus maiores como peritos em alguma arte, se ele próprio se treinar nela, presumese que ele mesmo nela seja perito, o que se nota para os filhos dos doutores e para os filhos dos advogados" (Macedo, Perfectus doctor [...], cap. 1). Embora não se tratasse de uma consequência forçosa, uma vez que se pressupunha o estudo do direito, o certo é que a geração nobre condicionava duplamente a aquisição do hábito de jurista. Pois, além de favorecer aqueles que tinham uma geração distinta, quase que fechava as portas aos que não tivessem, por nascimento, esse patrimônio moral. Mesmo os que, nascidos plebeus, tivessem se tornado nobres, apenas seriam capazes de "um saber sem nobreza", sendo intolerável para os nobres que exercessem funções docentes, mormente se, suplementarmente, fossem "de nação infecta". ${ }^{13} \mathrm{O}$ exemplo de juristas famosos de geração defeituosa (como Bártolo, Jasão e João de Andreia, que eram bastardos) podia atenuar essas presunções. Em todo caso, há testemunhos de que o defeito "mecânico" costumava ser escusado. ${ }^{14}$

Porém, independentemente da geração e até superando esta, havia a eficácia da ciência para gerar a nobreza (Lange, 1980, p. 279-294). De fato, toda a tradição do direito acadêmico insistia, desde a Idade Média, no caráter nobilitante do saber e em que a nobreza adquirida pela ciência era mais forte do que a transmitida pelos pais. Esta última seria apenas uma presunção de que as virtudes dos pais se continuavam nos filhos. Ao passo que a nobreza pela ciência consistia em uma virtude própria, da alma e dos bons costumes ("nobilitas tinha escrito Bartolomeu de Saliceto (falec. 1411) — est filia scientiae, quae nobilitat interius, \& exterius; interius, quia illuminat intellectum; exterius intellectus, ita illuminatus, corpus bene regit, bonis instruens moribus", a nobreza é filha da ciência, que nobilita interior e exteriormente; interiormente, porque ilumina o entendimento; exteriormente, porque o entendimento assim iluminado governa bem o corpo, ensinando-lhe bons costumes). ${ }^{15} \mathrm{E}$, assim, a nobreza provinda da ciência não era apenas uma presunção, mas uma verdadeira nobreza, que residia verdadeiramente na alma e que, portanto, era mais importante e útil (Gil, 1613, p. 3).

Daí que os doutores graduados nas universidades, ainda que aí não ensinassem, fossem nobres segundo o ius commune, privilégio que se estenderia aos licenciados e ainda beneficiaria em parte os bacharéis. Desde que ensinassem, os doutores eram logo intitulados de clarissimi; e se perfizessem 20 anos de docência, tinham, por direito comum, o título de duques ou de condes (Macedo, [16]43, p. 4).

${ }^{13}$ Macedo ([16]43, cap. 2, c. 5). Sobre o tema dos cristãos-novos, ver adiante.

${ }^{14}$ Cunha (1743, cap. 8, Da nobreza, que he necessaria ao Ministro, p. 62 [a mecânica é justo que se dispense e se costuma, n. 4, p. 64]).

${ }^{15}$ Op. cit. por Gil (1618, cap. 1, p. 3). 
Como essa nobreza não era nativa, mas um reflexo do saber, essas distinções apenas cabiam aos doutores sábios, ${ }^{16}$ e não àqueles que apenas sabiam um direito engolido às pressas. ${ }^{17}$ As expressões para fustigar os falsos doutores multiplicam-se: os que estudam apenas pelos repertórios, não curando dos fundamentos do direito; os que não são doutores (doctores), mas dores (dolores); aqueles cujos livros se cobrem de pó; os que apenas procuram agradar; os que alegam leis que são tão pertinentes ao caso como um burro voar; os doutores "das dúzias"; os que disputam acerca de trivialidades (lana caprina), como saber se de quem é o pintainho de um ovo posto por uma galinha e chocado por outra; os doutores "de necessidade" (pois "a necessidade faz a lei"); os doutores "moeda cerceada", pois, tal como essas moedas, "não têm letras" (Macedo, [16]43, p. 40).

A nobreza dos doutores se estenderia aos advogados, pessoas "egrégias" e que se reputavam de nobres. ${ }^{18}$ Também essa distinção apenas se aplicava aos que fossem exigentes quanto às questões jurídicas, doutos, bons jurisconsultos, inofensivos, bons homens e tementes a Deus. Mas não abrangia os advogados ignorantes de direito, como seriam muitos dos que exerciam em terras pequenas como procuradores: os estranhos à classe, os rábulas ou tagarelas, os palavrosos importunos, os que, para buscar seu lucro, desprezavam o direito e punham em risco a vida e a fortuna dos clientes (Macedo, [16]43, p. 43).

Muito importante para essa época, na castiça sociedade ibérica, era a questão da limpeza de sangue como condição para o acesso à dignidade de doutor, nomeadamente em direito. Usamos um texto de Jerónimo da Silva Araújo (1743), ${ }^{19}$ da primeira metade do século XVIII (1743), para seguir a questão, tanto em suas formulações mais correntes quanto na opinião bastante singular de seu autor, crítica da exclusão dos cristãos-novos dessa elite letrada. A questão era discutida desde os finais do século XVI, tendo sido abordada por Jorge de Cabedo, Diogo Guerreiro Camacho Aboim, Melchior Febo, Manuel Álvares Pegas e outros. ${ }^{20}$ A generalidade desses autores defendia que a exclusão dos cristãos-novos se justificava por várias razões. Por um lado, era o reflexo da interdição de acesso dos conversos a cargos públicos e dignidades. ${ }^{21}$ Por outro, no caso da advocacia, chocava com o princípio de que o advogado inimigo de uma das partes podia ser recusado. Ora, diziam, não havia maior presunção de inimizade do que a que o direito presumia existir entre cristãos-novos e cristãos-velhos (Araújo, 1743, cap. 49, n. 10-11, p. 206). Porém, Jerónimo de Araújo, estri-

\footnotetext{
16"Doctor sine scientia est ut Comes sine comitatu, \& fons sine acqua" (Macedo, [16]43, p. 42).

17"Qui potius est Doctor juris sorbibilis, quam civilis" (Macedo, [16]43, p. 40).

${ }^{18}$ Ver Macedo ([16]43, p. 43); também, Gil (1613, cap. 1, n. 1ss.).

${ }^{19} \mathrm{O}$ autor (n. 1.706) era bacharel em direito canônico e advogado em Lisboa. Pertenceu à elite culta de seu tempo, sendo nomeado para a Academia Real de História. Tinha relações com outros acadêmicos eruditos, frequentadores de livros, como d. Diogo e d. Francisco da Gama, filhos do primeiro conde de Assumar, os advogados Domingos de Sá e Silva, Francisco da Mota e Veiga, Emanuel Pinto da Silva, o desembargador João Alvares da Costa, bem como com membros da Congregação do Oratório.

${ }^{20} \mathrm{Cf}$. Ord. fil., 5, 117; Araújo (1743, cap. 49, n. 5-9, p. 204ss.)

${ }^{21}$ Ver Pegas (1703), ad Ord. fil., 1,35,8, cap. 3.
} 
bado na afirmação enfática de sua pureza de sangue, tinha outra opinião: "Sou cristão-velho e a minha família desempenhou com fidelidade cargos públicos. Mas somos todos filhos de Adão. Quantos cristãos-velhos foram condenados, enquanto muitos cristãos-novos se salvaram pela fé em Jesus" (Araújo, 1743, cap. 49, n. 12). Daí que, prossegue, os cristãos-novos pudessem ter fama pública de virtude sem tergiversação. E se o juiz brilhasse pela virtude e pela sabedoria, nada mais se lhe devia pedir (Macedo, Perfectus doctor [...], cap. 49, n. 13).

Elevando o plano da argumentação para o nível supremo da teologia, acrescentava que era comum a afirmação de que Deus não aprovaria a consideração de circunstâncias pessoais (acceptatio personarum) na avaliação dos méritos espirituais, pois isso seria injusto (odioso). Por isso, os que distinguiam gentios convertidos e judeus convertidos mostravam desprezar a unidade da Igreja ${ }^{22}$ e desrespeitavam o estabelecido nos cânones que protegiam os cristãos-novos contra a exclusão de ofícios e benefícios. ${ }^{23}$ Muitos afirmavam, remata, que isso era como que herético (quasi haeaeticum). ${ }^{24}$ Daí proviria a posição complacente do direito de Castela, em que os conversos não eram excluídos dos ofícios, antes chamados a eles. ${ }^{25}$

O remate da argumentação é uma enorme provocação à sociedade casticista: "Acresce que os nobres têm preferência nos ofícios, e os judeus são mais nobres por sangue e antiguidade das famílias do que quaisquer outros, deles descendendo muita da nobreza na França e, sobretudo, na Espanha" (Macedo, Perfectus doctor [...], cap. 49, n. 16).

"Mas" - conclui o autor, simulando prudência, depois de uma argumentação que culminava com a acusação de heresia ("e poderia acrescentar mais coisas que encheriam um livro inteiro", Macedo, Perfectus doctor [...], cap. 1, n. 18) — "não te afastes da opinião comum e recusa ao cristão-novo a cadeira de juiz", pois essa seria a opinião comum, atestada por Manuel Barbosa, ${ }^{26}$ António Cardoso do Amaral, ${ }^{27}$ Francisco Caldas Pereira. ${ }^{28}$ "Nesta matéria calo-me e aproveito dos votos dos outros. Apenas digo que eles, se tiverem virtude, adorarem a Deus e não tiverem culpa nos feitos dos antepassados e são dignos de honras. Pois não são de rejeitar os que Deus aceitou. Nem se deve excluir quem descende de judeus, se os antepassados forem bons [...]. Não reputo meu inimigo um cristão-novo. E basta. É que a matéria é odiosa e eu não quero prejudicar ou ofender ninguém" (Macedo, Perfectus doctor [...], cap.. 49, n. 20).

${ }^{22}$ Cita Barbosa, I. 3, vot. 93, n. 49 e 71 (Pedro ?; Agostinho ?)

${ }^{23} \mathrm{Na}$ verdade, provar-se-ia pela autoridade dos concílios que os conversos deviam ser admitidos às prebendas, pois nem todos os judeus tinham contribuído para a morte de Cristo. Por que estender então a todos as leis, autoridades e desprezo? (Araújo, 1743., cap. 49, n. 15).

${ }^{24}$ Ver Araújo, 1743., n. 14.

${ }^{25}$ Cita Part. 7, 24, 6, in fine (porém, ver Part., 1,6,5; 7,14,3).

${ }^{26}$ Cita Manuel Barbosa, Remissiones doctorum, ad. I,48, § 25, n. 2.

${ }^{27}$ Cita Liber utilissimus [...], ver "Officiallis", n. 51; ver "Procurator", n. 110.

${ }^{28} \mathrm{Cita}$ Questiones forenses. cons. 13, n. 7. 
Apesar dos pontos de vista reformistas — que não abrangiam os judeus, mas apenas os conversos (cf. a parte final de cap. 49, n. 20) - Jerónimo de Araújo constata como, em seu tempo, as interdições de acesso ao estatuto de letrado se mantinham em vigor.

A identificação entre a qualidade do jurista e a nobreza familiar conflituava com a exigência de qualificações profissionais. Nomeadamente, nos conselhos palatinos, em que nobres e juristas lutavam arduamente entre si por prestígio e poder. Sinais dessa rivalidade aparecem, por exemplo, no Dialogus, de Matienzo, a propósito da distinção usual entre nobreza adquirida e generativa (III, max. caps. 3 e 4), Matienzo valoriza os méritos pessoais, a posição que convinha aos letrados, que, pelos estudos, tinham chegado aos topos da administração. Por isso, adere à opinião de Lucca de Pena sobre a superioridade das virtudes pessoais como fundamento da nobreza, sustentando que os nobres por sapiência, virtudes e bons costumes preferiam àqueles que tinham obtido sua nobreza por geração, riqueza, privilégio ou dignidade. Em seus esforços para desvalorizar a nobreza por geração em face dos grupos burocráticos emergentes que a reclamavam com base nos méritos pessoais, lança um inesperado ataque à nobreza de sangue: "a nobreza [generativa] não é mais do que a riqueza antiga; portanto, os nobres provêm da iniquidade: todos são iníquos ou herdeiros de iníquos" (Macedo, Perfectus doctor [...], III, cap. 4, p. 49). Apesar desse ataque áspero contra a nobreza tradicional - uma manifestação da violenta polêmica entre "armas" e "letras"29 —, Matienzo não põe em causa a ideologia aristocrática do Antigo Regime. Os nobres em geral prefeririam os plebeus, embora apenas quando as respectivas virtudes se equivalessem (Macedo, Perfectus doctor [...], III, cap. 4, p. 50 v.); o status familiar derivaria de pai para filho, pois o filho seria parte do pai (Macedo, Perfectus doctor [...], III, cap. 4, p. 52). Paralelamente, de uma linhagem vil presume-se que nasça uma prole também vil ("é raro que um filho honesto nasça de um pai mau, tendo antes a natureza do pai, tal como uma árvore má não pode dar bons frutos” (Macedo, Perfectus doctor [...], III, cap. 4, p. 52). Na verdade, essa ideologia da continuidade das virtudes familiares revelou-se útil ao grupo dos juristas, justificando, nomeadamente, a valorização dos antecedentes familiares na escolha dos magistrados: o brilho dos ancestrais dos candidatos devia ser considerado, de modo que "aqueles que têm pais ou antepassados honrados em cargos públicos têm um direito hereditário quase jurídico (quasi legalis) a reivindicar os cargos da república" (ibid., p. 51 v.). E era isso que acontecia na prática. O jurista Diogo Marcão Themudo, um decisionista conhecido nas elites jurídicas portuguesas do século XVII, pediu para um filho seu despacho para um lugar de juiz (de fora) em uma terra de primeiro banco (nas cortes), por ser esse o costume. ${ }^{30} \mathrm{Na}$ mesma fonte arquivística, encontramos o registo do pedido feito por um Lourenço Correia de Lacerda, de um lugar de desembargador na Casa do Cível para o filho, logo que este tenha 12 anos, em recompensa

\footnotetext{
${ }^{29}$ V. Buescu (1996, p. 177ss.); "Questão he vulgarmente ventilada entre os Políticos qual seja mais nobre faculdade se a das letras ou a das arma". Arquivo Nacional da Torre do Tombo (ANTT). Miscelâneas manuscritas, n. 1112f.1.

${ }^{30}$ ANTT. Desembargo do Paço, Repartição da Justiça, Livro de registo de consultas, n. 32, p. 15, 1654.
} 
dos méritos e serviços de seu pai. ${ }^{31}$ A nobreza dos juristas gerava privilégios, sublinhando e garantindo sua distinção social. ${ }^{32}$

Que privilégios eram esses? De reino para reino, eles variavam. Mas existia um núcleo comum, estabelecido pelo direito comum. Gozavam dos privilégios genéricos da nobreza, que se traduziam na isenção de todos os tributos que apenas incidissem sobre a plebe (Pereira, 1662, n. 1.399, 1.406), na imunidade em relação a todos os encargos pessoais e ofícios da república (Pereira, 1662, n. 1.401), no direito de "homenagem" ou cárcere doméstico (Pereira, 1662. 1.402), no privilégio de poderem recusar-se a testemunhar (Pereira, 1662, 1.403), na isenção de tortura (Pereira, 1662 n. 1.404) e de penas próprias dos plebeus (Pereira, 1662., n. 1.405), na possibilidade de recusarem a nomeação para tutor (Pereira, 1662, n. 1.400), na prerrogativa de usarem armas (Pereira, 1662, n. 1.405). Podiam expulsar os vizinhos que, pelo barulho, cheiros, intranquilidade, perturbassem seus estudos (Pereira, 1662, n. 1.398), não podiam ser presos durante a audiência (Gil, 1613, cap. 13, n. 14), e seus livros eram impenhoráveis (Gil, 1613, cap. 13, n. 5-7). Tinham, para além disso, prerrogativas simbólicas, como o direito ao título de conselheiros do príncipe (Pereira, 1662, n. 1.407) e à reverência dos juízes, perante os quais podiam sentar-se (Pereira, 1662, n. 1.407). Nem todos esses privilégios estariam incorporados nos direitos locais das monarquias ou das cidades. Mas, em contrapartida, muitos outros podiam estar em uso (Pereira, 1662, n. 1.408-1.413). No conjunto, nada para desprezar, tanto no plano imediato de direitos efetivos quanto no plano mais mediato da construção de uma imagem pública.

Sobre seus discípulos, o direito comum atribuía-lhes certa jurisdição, como juízes de seus alunos e ouvintes. Como o direito do reino não ratificava isso, permanecia apenas um poder simbólico, ligado à dignidade de seu saber (Pereira, 1662, n. 1.316-1.317). Porém, cabia- The um importante poder no domínio de sua gestão da consciência dos discípulos - concebido como uma forma de potestas oeconomica, semelhante à do pater sobre seus filhos - , pois podiam, com sua doutrina, obrigar gravemente a opinião dos discípulos ("in materia gravi... sub lethali paccato", Pereira, 1662, n. 1.318), aos quais podiam ainda impor uma disciplina externa e aplicar penas módicas, adequadas a tornar esta efetiva ("fraternitaliter corrigere", Pereira, 1662, n. 1.321: "[...] solum posse posse ob objurgationes, verba, et percussiones non atroces. Neque potest in illos animadvere, in quos, vel propter aetatem, vel propter alias circunstantias, consuetum non sit animadvertere. Neque posset excedere limites consuetos, facultatemve seu beneplacitum"). ${ }^{33}$

\footnotetext{
${ }^{31}$ ANTT. Desembargo do Paço, Repartição da Justiça, Livro de registo de consultas, n. 32, p. 4, 16 e 114, 1654.

${ }^{32}$ Sobre os privilégios dos doutores, ver Pereira (1662, lib. 8, disp. 1, n. 1.151ss.); sobre seus graus e precedência, disp. 1 , n. 1.281ss.; sobre seus poderes (sobre os discípulos e ouvintes, de interpretação, de gerar opiniões de autoridade, de determinar sobre coisas religiosas), disp. 3, n. 1.315ss.; sobre seus privilégios, disp. 4, n. 1.361ss. Sobre os privilégios dos advogados, ver Gil (1613, cap. 13).

${ }^{33}$ Punição dos excessos, ver Pereira (1662, n. 1.323).
} 
Notável era também o estatuto de que gozavam suas interpretações das Escrituras, dos cânones e das leis (Pereira, 1662, n. 1.329ss.). Quanto à interpretação das leis, embora sua interpretação não pudesse ser tida como autêntica, já que esta era exclusiva do príncipe, ela era legítima, mesmo quando proibida pela lei, desde que não fosse frívola e contrária ao espírito da lei ou às regras do direito (Pereira, 1662 [...], n. 1.333). O alcance dessa faculdade de interpretar a lei fica mais claro se se atender ao que se entendia serem as pretensões das opiniões dos doutores a alcançarem o estatuto de opiniões prováveis ou comuns, as quais, segundo o direito, criavam direito. A condição requerida para que a opinião de um especialista alcançasse essa autoridade era a de que tivesse em conta todos os pontos de vista ("nulla discussione praetermissa ... pro utraque parte diligenter examinata", Pereira, 1662, n. 1.338). Na opinião do jesuíta Bento Pereira, que vimos seguindo, isso restringia a aplicação do preceito aos doutores famosos (de que cita seus companheiros Suarez, Molina e Tomás Sanches), segundo a opinião dos melhores. A multiplicação da opinião era a pedra de toque de sua autoridade, pelo que a aceitação pela maioria aparecia como provável. Se fosse seguida por todos, então criaria a obrigação de observá-la como lei (Pereira, 1662, n. 1.343). ${ }^{34}$

Nunca é demais salientar o alcance desse "privilégio intelectual" de dizer o direito, reclamando uma especial certeza. Em um direito disperso, confuso, hermético, privado de autoridades formais decisivas, o estabelecimento dos padrões de conduta e a resolução de conflitos acabavam por pertencer a esse grupo, que estabelecia normas a partir da autoridade moral de suas almas e da fiabilidade intelectual de seus processos de discorrer. Mas do que quaisquer privilégios institucionais - mesmo o tão abrangente privilégio de nobreza -, era principalmente isso que criava a autoconfiança do grupo e contribuía para sua distinção social.

Para além dessas importantes prerrogativas intelectuais, muitos tinham sido os privilégios concedidos pelos papas, imperadores e príncipes (Pereira, 1662, n. 1.363), embora estes também estivessem dependentes de se verificarem as condições espirituais em que assentavam - ciência, bom nome, vida honesta e exercício de sua função (Pereira, 1662, n. 1.364, 1.384-1.385, 1.395). Excluídos estavam ainda os que tivessem sido mal graduados (Pereira, 1662, n. 1.365). ${ }^{35}$ Os privilégios estendiam-se a familiares próximos, nomeadamente aos filhos, mas também, sob certas condições e em determinados âmbitos, aos irmãos e cônjuge (Pereira, 1662, n. 1.376-1.382).

De reino para reino, os privilégios de direito particular variavam.

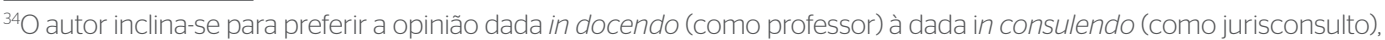
pois a primeira seria mais exaustivamente fundada e mais independente das opiniões das partes (Pereira, 1662, n. 1.346). ${ }^{35}$ Mas não, significativamente da moderna exaltação do príncipe como fonte de virtudes, os que tivessem sido graduados, não pela universidade, mas por rescrito do príncipe (Pereira, 1662, n. 1.368-1.372). 


\section{Riqueza (divitiae)}

Já a riqueza não era, em princípio, exigida aos juristas. Teria mesmo certos inconvenientes: favorecia a negligência, seria incompatível com a virtude. Mas, por outro lado, permitia um ócio favorável (Macedo, [16]43, qual. 3, p. 20) (Macedo, Perfectus doctor [...], cit. cap. 7, p. 20). Sendo ambos os extremos viciosos, elogiava-se por um mediano ideal, embora mais próximo da riqueza, pela tranquilidade de espírito que daria. Ao que acresceria um fator relacionado com a dignidade, o esplendor e a reputação de que os juristas eram credores: "hoje em dia, não se reputa ninguém digno de honra senão os ricos". Se o rico fala, escreve, suas palavras sobem até às nuvens. Se o pobre diz alguma coisa, logo preguntam: "Quem é este?". ${ }^{6}$ Assim, diz que, entre dois doutores de iguais méritos, é de considerar a riqueza, pois a dupla razão do mérito e da riqueza tem mais força do que uma única razão ("duo vincula magis stringunt") (Macedo, Perfectus doctor [...], cit. cap. 7, p. 22).

De fato, a riqueza - ou, pelo menos, a abastança - cumpria a função de permitir que a dignidade da pessoa se manifestasse, na morada e no trajar. Por isso, Jerónimo da Cunha aconselha um trem de vida que evidenciasse a distinção.

Que o Juiz podendo occupe casas boas, não sendo demasiadas a respeito da sua família [...]. Se tiver dentro nellas algum jardim, quintal, ou cerca, será utilíssimo para o seu justo recreyo, e assim evitará muitas sahidas, tendo dentro de casa tal, ou qual divertimento, o que he louvável; pois o não recusão, os que professão a mais perfeita vida; e assim isto não entra na demasia. Póde ter dous, ou tres criados, que o sirvão, hum bom cavallo, ou dous; ouro, e prata, quanta puder; e todas as alfaias de casa, que reputar precisas ao seu estado, e já digo, que conforme as suas rendas. Convém que o Ministro seja opulento, e estas mesmas conduzem para a estimação, se bem que o pobre a pode conseguir com menos. No particular da sua livraria tenha quantos livros puder, que nisto não ha excesso, havendo com que se comprem [...]. (Cunha, 1743, p. 80).

\section{Habitus e comportamento}

Não eram apenas as caraterísticas físicas que revelavam disposições anímicas. Também os comportamentos externos - como o andar, o vestir, o comer, os lazeres, o trem de vida doméstica e outros hábitos - revelavam os estados interiores, para além de contribuírem

36"Sed quid ex duobus extremis? divitem eligo, tum quia ultra notata, divitia serenant animam, anima autem quiescendo fit fapiens, tum quia hodie nemo nisi dives honore dignus reputatur" (Macedo, [16]43, qual. 7., p. 21). 
para a formação da fama e, com isso, da credibilidade pública. E, por isso, a literatura exemplar abunda em conselhos quanto às maneiras e aos hábitos dos juristas.

A matéria dos costumes é interessante para avaliar a imagem que o grupo dos juristas entendia dever dar de si mesmo. Em uma sociedade de comportamentos codificados como era a sociedade moderna, o porte de cada um devia ser verdadeiro, honesto, ou seja, revelar a natureza íntima das pessoas ou dos estados, excluída toda a afetação e a dissimulação, tão apreciadas pelos doutrinadores da cultura de corte. ${ }^{37}$ Nisso consistia a "honra", como em tempos destacou Maravall (2007 [1989]). Nesse caso, tratando-se de comportamentos grupais ou estatutários, eles deviam tornar possível uma leitura imediata da natureza daquele estado, de sua função na ordem social.

Assim, estavam interditos aos juristas os comportamentos que contradissessem a severidade e a dignidade de sua função. Era o caso dos jogos de azar, como os dados ou os "pauzinhos" (mikado), dos que perturbassem a gravidade, dos que - embora industriosos (como o xadrez) - fizessem perder tempo (Macedo, [16]43, qual. 9, p. 23ss.). Igualmente proibidos eram os comportamentos que atentassem contra a dignidade, como o porte soberbo, $\mathrm{o}$ autoelogio, o andar armado e a vagabundagem (Macedo, [16]43, p. 26-27). A verbosidade deveria ser evitada, por ser um sinal de tolice, além de comprometer a gravidade e a discrição: "temos dois ouvidos e uma só boca, para que ouçamos muito e digamos pouco" (Macedo, [16]43, p. 27). Pelo contrário, o porte físico devia ter compostura e gravidade (Macedo, [16]43, p. 26). Os cabelos não deviam ser tingidos ou penteados de forma afetada. No vestir, deviam evitar-se o luxo, as cores variegadas, a abundância de peças de roupa, a extravagância (HargreavesMawdsley, 1963); nos dias de festa, era sinal de rusticidade o vestir-se melhor. Na decoração da casa, deviam ser discretos (Macedo, [16]43, p. 32-33). Deviam fugir de passatempos libidinosos, pois "nada haveria mais oposto à ciência do que a voluptuosidade" (Macedo, [16]43, p. 23). Deviam comer carne (de preferência de carneiro) ou peixe, como alimentos nutritivos. E fugir de muito queijo, azeite, cebola e óleo, alimentos gordos, que não conviriam ao bom juízo. O beber vinho devia ser moderado e adaptado ao temperamento - tinto para os robustos e laboriosos, branco para os de vida sedentária embora o vinho aguçasse o engenho (Macedo, [16]43, p. 29) (Cunha, 1743, cap. VI, Do vício do vinho, p. 49). Enfim, deviam fugir de comer muito, pois, quanto mais forte era o corpo, mais fraca seria a alma ("pinguis venter tenuem sensum non gignit" - um ventre pingue não gera um espírito sutil). Daí que se dissesse que Bártolo pesava os alimentos ("não te rias disto" — adverte Macedo - "pois é sabido quanto cuidado e estudo os professores italianos põem no favorecimento do engenho", Macedo, [16]43, p. 30).

${ }^{37}$ Central: Castiglione (1528). Ver Ossola e Prosperi (1980) e Burke (1996). 
Em resumo,

[...] fugir das coisas libidinosas do ventre e das goelas, do culto ou ornato imodestos do corpo, dos jogos inúteis, do torpor do sono e da preguiça, da emulação e das rixas, do desejo de evidência, das honras e poder, evitar as inimizades e não fazer aos outros o que não se queira padecer, procurar amigos. (Macedo, [16]43, p. 28).

Matienzo, referindo-se à postura dos advogados, confirma esse ideal de comportamento corporal. ${ }^{38}$ Em sua opinião, o advogado, ao falar, ao requerer ou ao alegar alguma coisa perante o juiz, devia mostrar um rosto tranquilo e um parecer maduro no vulto (afável, benigno, justo) e no gesto. Devia manter a cabeça e os olhos imóveis, sem mexer as mãos, sem crispar a face e sem mexer os pés. A face devia estar composta e não perturbada ou feroz, sem elevar a voz, com um discurso não arrebatado nem afeminado, pois aos que vociferam parecia que lhes faltava a razão, suprindoa pelo espalhafato (garrulitate clamorosa), "para satisfazer o salário do cliente apenas com o vento e por alegações vazias que nada têm que ver com a substância da causa" (Matienzo, 1653, II, cap. 2, p. 33). Haveria ainda outros que se desviavam dos costumes quanto ao modo honesto de apresentar um caso, elevando a voz, limpando a cara, ajeitando o cabelo por cima das orelhas, elevando os olhos ao céu, suspirando, franzindo as sobrancelhas, levando a mão ao queixo, comprimindo os lábios e fazendo outras caretas para que parecesse que estavam a pensar, fulminando o auditório com voz tonitruante, recordando a fábula (de Fedro) em que a montanha dava grandes gritos ao parir, mas ao final parindo apenas um ridículo rato. ${ }^{39}$

Até na atitude corporal havia normas minuciosas, pois esta revelava a alma. Os advogados deviam exibir maturidade relativamente a três aspectos: na postura, no gesto e na voz. Na postura, deviam manter uma atitude gentil, alegre e doce em relação ao público, sem expressões faciais estranhas. No gesto, deviam evitar movimentos excêntricos da cabeça ou dos pés. Para que a postura em geral pudesse manifestar a seriedade e a maturidade intelectual, a disposição de outras partes do corpo também importava, desde a língua e os olhos até os pés. A voz não devia ser nem monótona nem exaltada, antes devia procurar elevar-se ao nível daquela gloriosa vox de que falavam algumas fontes: uma voz animada com a esperança da vitória, que saía do íntimo do peito, invocando saberes velhos e novos, citando com fidelidade doutores antigos e modernos, tudo a favor da causa que defendia, mostrando ao juiz seus méritos e preparando a vitória de seu cliente (Gil, 1613, cap. 4, n. 37). O olhar não devia parecer vago. A língua não devia ser nem frouxa nem petulante. O gesto deveria insinuar estudo e demonstrar o decoro e a verdade de um espírito reto. Além disso, a obscenidade

38Sobre advogados, Gil (1613): nobreza, cap. 1; qualidades, cap. 4 (p. 25); salário, cap. 6 (p. 55); privilégios, cap. 13 (p. 100).

${ }^{39}$ Matienzo (1653, II, cap. 2, p. 33ss.); em sentido semelhante (vulto afável, benigno e alegre, sem risos indiscretos, gesto grave, língua bem-composta e moderada, voz nem sumida nem exaltada), Gil (1613, n. 1, p. 97). 
do corpo, de palavras ou de atos também devia ser condenada. Cada prevaricador (em relação a qualquer desses padrões) era considerado uma pessoa traiçoeira, que favorecia apenas seus clientes ou cometia um roubo ao defendê-los de forma desonesta (Macedo, [16]43, p. 85-86; também Matienzo, 1653, p. 33).

Os trajos deviam também sugerir a postura interior: sabedoria, ${ }^{40}$ serenidade, discrição, serviço público. A toga, o sinal distintivo dos cidadãos romanos, devia ser a veste profissional dos advogados: decente e conveniente, sem o variegado das cores nem a multiplicação de peças (Gil, 1613, cap. 4, n. 9, p. 30).

Em um tom menos doutrinal e mais cético quanto à relação entre temperamento e comportamento e corpo, Jerónimo da Cunha (1743, p. 78) não deixa de estigmatizar os mesmos sinais de exagerado cuidado na aparência:

Parece-me mal aquelle, que entrando na Igreja, todo se está sacodindo, e namorando, com os olhos vagos, cercando tudo, e benzendo-se extravagantemente. Concerta a cabelleira, apalpa a volta, e arruma as dobras. Logo vay aos punhos, e até lhe não escapão os bicos dos pes. Tira o relogio, que esta curiosidade he vulgar na Igreja, logo a caixa [de rapé], a que se seguem assopros, e logo o lenço, e nisto se gasta a Missa. ${ }^{41}$

Embora conceda que a consideração pública do letrado tem suas exigências quanto à figura e à pose:

7. Porem com tudo não podemos negar, que o bom talhe, e figura conduz muito ao respeito dos juizes, em cujo aspeto se não devem notar deformidades com excesso; mas todas se soffrerão, excepto aquellas, que o impedirem a usar do seu officio, como v. g. a manqueira, ou cousa semelhante, e não excluiremos aos tortos; porque os vi já muitos direitos, sábios e rectos [...] O passo não deve ler muy accelerado, quando a occasião o não pedir, mas grave, e composto. Os olhos não devem andar fluctuando, e com presteza convêm que se retirem em bastantes occasiões: Não approvo o bracejar, que isso deixo eu aos arrieiros. Olhar para traz com dificuldade o admittirey, e acaso deve ser preciso com huma volta composta. Montando o Ministro a cavado, não deve hir atropellando, nem se meta a cavalleiro, sem saber hum pouco desta arte. Tempere a severidade com a amabilidade ; e finalmente vivendo em serviço

\footnotetext{
40"Vir bene vestitus.pro vestibus esse peritus./ Creditur à mile, quamvis idiota sit ille./ Si careat veste, nec sit vestitus honeste,/ Nullus est laudis, quamvis sciat omne, quod audit" (um homem bem-vestido é perito só pelo trajar. Se lhe falta o trajo ou não se veste de acordo com seu estado, não merece nenhum louvor, apesar de saber tudo o que ouve). Citado por Gil (1613, cap. 4, n. 9, p. 30).

${ }^{41}$ Cunha (1743, cap. X: do aspecto e presença; cap. XI, da pompa e tratamento, p. 76).
} 
de Deos, terá grande tranquilidade de animo, e elle fará o aspecto sereno [...]. (Cunha (1743, cap. X, p. 79). ${ }^{42}$

Esse comportamento ideal permitiria a prática do comércio? Essa era uma questão debatida e que exigia algumas distinções. ${ }^{43}$ Uma coisa eram as proibições dirigidas aos juízes, de comprar e vender, de aceitar penhores, de construir casas ou barcos no lugar de sua jurisdição, enquanto a exercessem. A razão de ser era, antes de mais nada, a de impedir que o juiz pudesse condicionar nos negócios pessoas sujeitas a seu poder (Matienzo, 1653, III, 27, p. 15-126).

Porém, a proibição do comércio (mercatura), como prática continuada, fundava-se, antes, na natureza alegadamente ignóbil dessa atividade, ideia já presente na Política (liv. 1), de Aristóteles (Meikle, 1996), e reafirmada na tradição romana. Nos doutrinadores da época moderna, a lição comum é a de que o comércio não apenas não dava nobreza como a retirava àqueles que a tivessem, a menos que houvesse lei em contrário. ${ }^{44}$ Isso quer dizer que o jurista, nobre por natureza segundo o direito comum, estava impedido de exercer o comércio, sob pena de perder essa nobreza - embora não seja claro o que é que isso implicava quanto ao exercício da jurisprudência. Fosse como fosse, a violação do preceito levaria à degradação da fama e da consideração pública, o que, no contexto da sociedade moderna, seria o suficiente para desencorajar o exercício da mercatura.

\section{Os vícios}

Às virtudes correspondiam os vícios, uns virtualmente comuns a todos, outros próprios de certas categorias de pessoas. A literatura deontológica dos juristas não os ignora. Por meio deles, podemos completar en creux o retrato ideal do jurista. ${ }^{45}$

Juan de Matienzo, em seu diálogo entre um advogado e um juiz (relator), põe os dois personagens a discutir com vivacidade sobre os defeitos de cada grupo (Matienzo, 1653, I). O relator - personificando o caráter de uma profissão legal tipicamente hostil à advocacia - acusa os advogados de estimular a litigiosidade (p. 21), lembrando que nas antigas cidades alemãs (ele também poderia ter se referido às cidades ibéricas) se concedia a leigos a

\footnotetext{
42Sobre os trajos, Araújo (1743, cap. 26, p. 118).

${ }^{43}$ Sobre o tema, ver Matienzo (1653, III, p. 27-32).

${ }^{44}$ Ver Matienzo (1653, III, cap. 28, p. 132). Com desenvolvimentos e distinções, Pereira (1662, lib. 8, disp. 1, n. 1.151ss.). "Doctores mercaturam exercentes suis privilegiis gaudere non debent. Ratio manifesta est quia in illis deficit per exercitium mercatura aut aliud simile utraque ratio motiva privilegiorum, scilicet dignitas qua obscuracor, \& exercitium docendi quod per aliud incompatibile cessat. Semper tamen requiritur sententia judicis, ut quis ab usu suorurn privilegiorum abstineat" (Pereira, 1662, lib. 8, disp. 1, n. 1.395).

${ }^{45}$ Sobre os vícios da elite togada, ver Pereira (1636, class. 5) e Jerónimo da Silva Araújo (1743, cap. 45).
} 
faculdade de defender as partes, e estes o faziam de forma rápida, pacífica e silenciosa ("brevi momento, pacifice, \& incredibili silentio") (Matienzo, 1653, I, cap. 8, p. 21). "Oh, litigantes miseráveis" - concluía ele -, "caindo nas mãos de doutores que põem as leis de pés para o ar [...]. É uma vergonha [...] ver interpretações tão diferentes nos jurisconsultos", que subverteriam a verdade, confundindo a simplicidade das partes com suas línguas e lábios retorcidas; como cães famintos, que só com comida seriam acalmados (Matienzo, 1653, p. 24). Por seu lado, o advogado defendeu seu grupo, argumentando que a ignorância jurídica dos leigos ainda multiplicaria as discussões e que os especialistas em direito seriam necessários para evitar conflitos, principalmente entre pessoas de temperamento forte, como os espanhóis.

Nos manuais de confessores da época, apareciam perguntas específicas relativas a pecados comuns nas profissões jurídicas. No do franciscano Rodrigo do Porto (1549), havia um capítulo sobre "Preguntas acerca d'alguns estados" (cap. 25). E aí se listavam as perguntas que os confessores deviam dirigir especialmente aos juízes (p. 423ss.), aos advogados e procuradores (p. 433ss.), aos tabeliães (p. 447ss.), aos mestres e doutores (p. 450ss.), aos escolares (p. 453ss.). Alguns anos mais tarde, o célebre manual de Martim de Azpilcueta (1549) inclui também títulos específicos sobre alguns estados (cap. 25), entre os quais os juízes (p. 493), os advogados e procuradores (p. 501), escrivães e tabeliães (p. 514), mestres e doutores (p. 516).

\section{A imagem popular dos juristas}

Contrastando com a imagem autoindulgente dada pelos textos legais, a representação comum dos juristas era - já o vimos - muito menos lisonjeira. Em toda a Europa, a literatura leiga ou popular costumava castigar juízes e advogados como pessoas que pervertiam ou torciam o direito tradicional com inovações supérfluas ou interesseiras; que rodeavam o direito de segredo - mesmo em nível linguístico - para monopolizar seu conhecimento; que usavam artimanhas, falácias e enganos para levar a cabo seus propósitos gananciosos; que constantemente mudavam de opinião de acordo com quaisquer interesses de seus clientes (Kelley, 1988).

Durante os séculos XV a XVIII, a soberba altaneira dos juristas é continuamente sujeita ao ridículo e a insultos na poesia e no teatro populares. Aqui, a imagem dos juristas era a de sábios pretensiosos, de um saber oco por detrás do qual se escondia a cupidez, agentes que o Diabo mandou ao mundo para desavir as gentes, línguas de trapos cujas latinadas serviam para enganar o povo, forjadores de escrituras que prejudicavam os que não sabiam ler, corporação de malfeitores que se protegiam uns aos outros. Essa imagem muito negativa dos tribunais, dos advogados e dos juristas em geral alimentou revoltas populares contra os "doutores" e seu mundo: universidades, direito escrito, documentos e arquivos, magistrados 
letrados. De certa forma, essa onda antijurídica constituiu também um fator de desfavor dos altos tribunais e da elite judiciária (gens de justice) que explica a Revolução Francesa. ${ }^{46}$

\section{Conclusão}

Calculo que alguns leitores, interessados na história social dos juristas, tenham se exasperado com as frequentes imersões na literatura de ética ou de teologia, ou com as tecnicidades do modelo argumentativo do discurso jurídico, a que dediquei parte do texto.Porém, isso tem a ver com um entendimento acerca de como fazer a história de pessoas ou de grupos, que se traduz em supor que os comportamentos assentam em avaliações acerca do mundo, dos interesses próprios e alheios e da forma adequada de os prosseguir. Quer o façamos por automatismos psíquicos, quer os tracemos em função de estratégias pensadas, na raiz da vontade de ação estão imagens que se situam no foro interno. ${ }^{47}$

Daí que os tais excursos na literatura de ética ou de teologia moral visavam a justamente reconstituir o processo de formação dessas imagens do corpo dos juristas sobre o mundo e sobre si próprio, imagens a partir das quais se desenvolviam comportamentos. Na verdade, essas imagens fazem parte de um intertexto formado pela tradição literária com que esse grupo lidava e na base da qual comunicava e se justificava, interna e externamente. A credibilidade desse imaginário - e das práticas que ele gerava e justificava - dependia de sua consistência com saberes diferentes do direito, como a teologia, a medicina, a filosofia natural. Mas também com a tradição literária do próprio direito.

Daí que as práticas dos juristas, como corpo especializado, têm de ser contextualizadas com essa tradição literária, com as suas figuras de estilo - metáforas e comparações, argumentos ou razões, referências de autoridade - , antes porventura de se saber de sua consistência com as estratégias sociais do grupo. A arqueologia das práticas dos juristas parece-me ser, antes de mais nada, uma arqueologia de imagens e ideias, antes de ser uma arqueologia de interesses ou lutas sociais.

Com isso, surge outro fator que perturba os historiadores gerais ou os de história social. A compreensão desses universos textuais de referência exige um estudo especializado que permita seguir as linhas de justificação, buscando as razões por detrás das razões. Daí a importância de incorporar a história do direito letrado e dos saberes de que este dependia sicut a matre sua na história social dos juristas. Se a história do direito não pode ficar exclusivamente entregue a juristas, também a história social do direito e dos juristas não pode pôr

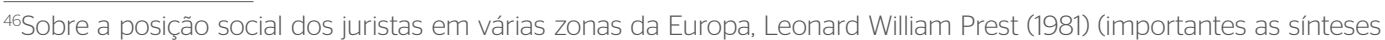
dedicadas a Inglaterra, França e Espanha).

${ }^{47}$ Um pouco mais dessa hipótese de trabalho em Hespanha (2003, p. 823-840). 
entre parênteses o fato de que as normas jurídicas dependem, antes de tudo, do convencimento que os agentes jurídicos têm de sua justificação. E o mesmo se diga dos comportamentos profissionais desses agentes. Só depois depende de sua oportunidade no contexto das lutas sociais. Ora as justificações dos juristas seiscentistas vão-nas eles buscar às imagens que tinham da dignidade de seu saber, da eminência do objeto desse saber e das virtudes que permitiam cultivá-lo. Tudo isso era matéria tratada por teólogos, moralistas, filósofos e pelos mesmos juristas, na linguagem e no modo de discorrer dessas ciências.

Esse universo de referências constitui um fenômeno de longuíssima duração, mantendo-se fundamentalmente constante entre o século XI e meados do século XVIII, nomeadamente no coração da Europa culta de então. Os cânones de perfeição do jurista - e a própria expressão jurisconsultus perfectus - mantêm-se durante esse longo período sem grande alteração. Alguma especificidade que se possa notar no século XVI — uma maior sensibilidade ao rigor e à certeza do discurso (Kelley, 1988) - é algo que não desmente essa ideia de séculos de um sacerdócio da justiça como uma missão de garantir a ordem do mundo em seus aspectos mais comezinhos ou mais elevados.

Muito interessante é analisar como essa visão interna ao grupo se disseminou na sociedade e foi partilhada por grupos distintos. Vimos que - apesar do arsenal de ritos sociais e de mecanismo de inculcação (da majestade, serenidade e sabedoria do grupo) que foram referidos - isso não se realizou, antes existindo visões externas dos juristas que não comungavam dessa imagem ideal dos próprios e que lhe eram muito desfavoráveis. Interessante é, porém, notar que os vícios que se apontavam aos juristas e que minavam o prestígio social do grupo eram os que correspondiam à violação da tal imagem normativa que o corpo criara — a arbitrariedade, contra a observância da regra; a falsidade, contra a verdade; o hermetismo, contra a clareza; a parcialidade, contra a neutralidade; a cupidez, contra a generosidade; a vilania, contra a nobreza. O ideal, na verdade, não era posto em causa. O que se dizia era que os comportamentos concretos não seguiam esse padrão ideal de um jurista perfeito, que parecia ser aceito pelos não juristas. Ora a adesão a esse ideal, ainda que continuamente violado, era um formidável trunfo simbólico para os juristas, em suas lutas sociais. 


\section{Referências bibliográficas}

AEGIDIUS, Benedictus [Bento Gil], Tractatus de jure, et privilegiis honestatis [...], Olyssipone, Petrum Craesbeck, 1618.

ALMEIDA, Eduardo. Sátiras políticas de seiscentos. Revista de Guimarães, n. 50, p. 172 ss., 1950.

ALMEIDA, Joana Estorninho de. A forja dos homens: estudos jurídicos e lugares de poder no séc. XVII. Lisboa: ICS, 2004.

AJELLO, Raffaele. Arcana juris: diritto e politica nel settecento italiano. Jovene editore: Naples, 1976.

ÁLVAREZ, Fernando Bouza Álvarez. Corre manuscrito: una historia cultural del siglo de oro. Madri: Marcial Pons, 2001.

ARAGÃO, António Barnabé de Elescano Barreto e. Demetrio moderno ou o bibliografo juridico portuguezo qual em huma breve dissertação historica e critica propôem e dá huma clara e distincta ideia de todas as preciozas reliquias e authenticos monumentos antigos e modernos da legislação portugueza. Lisboa: Lino da Silva Godinho, 1781. Disponível em: 〈http://purl.pt/431〉. Acesso em: fev. 2017.

ARAÚJO, Jerónimo da Silva de [Hieronymii Syevii de Araújo]. Perfectus advocatus: tractatus de patronis, sive advocatis, theologicus, juridicus, historicus et poeticus. Ulyssipone: Joannis Baptistae Lerzo, 1743. Disponível em: 〈http://purl.pt/16657m ou http://purl. pt/16657/4/sc-47066-v_PDF/sc-47066-v PDF 24-C-R0150/sc-47066-v 0000 l-b t24C-R0150.pdf〉. Acesso em: jan. 2017.

AZPILCUETA, Martín de. Manual de confessores er penitentes que clara e breuemente contem a vniuersal decisam de quasi todas as duuidas q[ue] $\mathrm{em}$ as confissões soem ocorrer dos peccados, absoluições, restituyções, censuras e irregularidades/composto por ho muyto resoluto es celebrado Doutor Martim de Azpilcueta Nauarro [...] Acrecentado agora por ho mesmo Doutor [...]. Coymbra, por Ioam de Barreyra, 1560. Disponível em: 〈http://purl. pt/14550>. Acesso em: mar. 2017.

BARBAS HOMEM, António Pedro. Judexperfectus: função jurisdicional e estatuto judicial em Portugal, 1640-1820. Coimbra: Almedina, 2003. BARNI, Gianluigi Barni. Appunti sul Deperfecto doctore, di Emilio Ferrettti. Archivio Giuridico, p. 128138, 1960 [1588].

BAROJA, Julio Caro. La cara, espejo del alma: história de la fisiognomica. Barcelona: Galaxia Gutenberg, 1993.

BARROS, Maria Cândida Drumond Mendes; FONSECA, Vitor Manoel Marques da Fonseca. Passagens do livro "Itinerário para párocos de índios", de Peña Montenegro (1668), em um confessionário jesuítico setecentista da Amazônia. Bol. Mus. Para. Emílio Goeldi. Cienc. Hum., Belém, v. 5.3, p. 669-679, set./dez. 2010. Disponível em: 〈http://repositorio.museu-goeldi.br/jspui/bitstream/123456789/522/1/ artigo_B\%20MPEG\%205(3)\%202010\%20 BARROS.pdf>. Acesso em: jan. 2017.

BLAIR, Ann. Too much to know: managing scholarlyinformation before the Modern Age. New Haven [Conn.]: Yale University Press, 2010.

BELLOMO, Manlio. The common legal past of Europe: 1000-1800. Washington, D.C.: Catholic university of american press, 1995 [ed. orig. ital. 1988].

BOURDIEU, Pierre. Esquisse d'une théorie de la pratique précédé de Trois études d'ethnologie kabyle. Genebra: Droz, 1972.

Le sens pratique. Paris: Les Éditions de Minuit, 1980.

BOUWSMA, William J. Lawyers and early modern culture. The American Historical Review, n. 78, p. 303-327, 1973. 
BROOKS, Christopher W. Pettyfoggers and vipers of the Commonwealth: the "lower branch" of the legal profession in early modern England. Cambridge: Cambridge University Press, 1986.

BUESCU, Ana Isabel. Imagens do príncipe: discurso normativo e representação, 1525-49. Lisboa: Cosmos, 1996.

BURKE, Peter. The fortune of the courtier: the European reception of Castiglione's Cortegiano. University Park/Pensylvania State University, 1996.

CABRAL, Gustavo César Machado. Os decisionistas portugueses entre o direito comum e o direito pátrio. Tese (Doutorado) - Faculdade de Direito, Universidade de São Paulo, São Paulo, 2013.

CALASSO, Francisco. Introduzione al diritto comune. Milão: Giuffrè, 1951.

CAMARINHAS, Nuno. Juízes e administração da justiça: Portugal e o império colonial, sécs. XVII e XVIII. Lisboa: FCG/FCT, 2010.

. Memorial de ministros, um dicionário biográfico de magistrados (séc.XVIII). Lisboa: Biblioteca Nacional. No prelo.

CAMOS, Marco Antonio de. Microscomia y gobierno universal del hombre christiano [...]. Barcelona: Pau Malo, 1592.

DESLAURIERS, Marguerite. How to distinguish Aristotle's virtues. Phronesis, n. 47.2, p. 101-126, 2002.

DIPLOVATACCIO, Thomaso. Liber de claris iurisconsultis, 1511 [Ed. contemporânea: Curantibus. Fritz Schulz, Hermann Kantorowicz [e] Guiseppe Rabotti. Roma: Institutum Gratianum, 1968].

FRAGOSO, Baptista. Regiminis reipublicae christianae [...]. Lugduni: Laurentij Anisson, 1641-1652. (Também Colonia Allobrogum: Fratrum de Tournes, 1737). Disponível em: 〈https://play.google.com/store/books/details? id=JdQ_AAAAcAAJ\&erdid=book $-J d Q$
AAAAcAAJ\&erdot=1〉; 〈https://play.google. $\mathrm{com} /$ store/books/details?id=sAOn5smWqKIC\&rdid=book-sAOn5smWqKIC\&rdot=1;; 〈https:/play.google.com/store/books/details?id=0EtEGhXIDj8C\&rdid=book-0EtEGhXIDj8C\&rdot=1>. Acesso em: fev. 2017.

GIL, Bento. Directorium advocatum et privilegiis eorum. Ulissipone: Pedro Craesbeck, 1613. Disponível em: ‘http://purl.pt/29465/5/ P5.html; http://purl.pt/29465/4/sc-2312-p_ PDF/sc-2312-p_PDF_24-C-R0150/sc-2312p_0000_capa-capa_t24-C-R0150.pdf $>$. Acesso em: fev. 2017.

GONÇALVES, Luis da Cunha. Gil Vicente e os homens do foro. 2. ed. Lisboa: Atica, 1953. [1. ed. 1939].

GÖTZ, Norbert. "Moral economy": its conceptual history and analytical prospects. Journal of Global Ethics, n. 1l, p. 147-162, 2015.

HALPERIN, Jean-Louis. Le juriste de la ville et l'homme des champs: le "De privilegiis rusticorum", de Rene Choppin. In: Mémoires de la Société pour l'Histoire du Droit..., 44e. Fascicule. Dijon: Editions universitaires de Dijon, 1987.

HARGREAVES-MAWDSLEY, W. N. A history of legal dress in Europe until the end of the eighteenth century. Oxford: Clarendon, 1963.

HERBERGER, Maximilian. Juristen, bösen Christen. Disponível em: 〈http://rechtsgeschichte-life.jura.uni-sb.de/Herberger_Juristen.htm>. HESPANHA, António Manuel. Savants et rustiques: la violence douce de la raison juridique. Ius commune, Frankfurt/Main, n. 10, p. 1-48, 1983. [Versão portuguesa (resumida): Revista Crítica de Ciências Sociais, n. 25-26, p. 31-60, 1988.].

. Justiça e administração nos finais do Antigo Regime. In: Hispania: entre derechos proprios y derechos nacionales. I. Milão: Giuffrè, 1989. p. 135-204. 
Qu'est-ce que la "constitution" dans les monarchies ibériques de l'époque moderne?. Themis: Revista da Faculdade de Direito da Universidade Nova de Lisboa, n. 4, p. 5-18, 2001.

Categorias: uma reflexão sobre a prática de classificar. Análise Social, n. 38.168, p. 823-840, 2003.

Direito moderno e intertextualidade: direito próprio e direito comum em De jure lusitano, de Mateus Homem Leitão (1645). Revista de História das Ideias: Tradição e Revolução. Homenagem e Luís Reis Torgal, n. 29, p. 47-102, 2008.

Como os juristas viam o mundo. 15501750: direitos, estados, coisas, contratos, ações e crimes. Create-Space (e-book e print on demand edition), Amazon-Kindle,2015a.

Os sentidos da motivação das sentenças na literatura jurídica pré-moderna. In: ANDREONI, Fernando; ALBERTO, Tiago Gagliano Pinto (Org.). Odever de fundamentação no novo CPC: análises em torno do artigo 489. Rio de Janeiro: Lumen Juris, 2015b. p. 27-39.

III. The law in the high and the late Middle Ages: the learned Ius commune and the vernacular laws. 18. Southern Europe (Italy, Iberian Peninsula, France). In: PIHLAJAMÄKI, Heikki; DUBBER, Markus; GODFREY, Mark (Ed.). Oxford handbook of European legal history. No prelo.

HORN, Norbert Horn. Soziale Stellung und Funktion der Berufsjurister in der Frühhzeit der Europäischen Rechtswissenschaft. Sozialwissenchaften im Studium des Rechts: Rechtsgeschichte. München: Beck, 1978. v. IV, p. 125-144.

KELLEY, Donald. Jurisconsultus perfectus: the lawyer as rennaissance man. Journal of the Warburg and Courtlaud Institutes, The Warburg Institute/University of London, n. 51, p. 84-102, 1988. Disponível em: 〈https://www.jstor.org/ stable/751264?seq=1\#page_scan_tab_contents’. Acesso em: mar. 2017.

LANDIM, Nicolau Coelho. Nova et scientifica tractatio utrique foro perutilis. I. De syndicato. II. De Malefactoribus.III.Desalariisofficialium. Ulysipone: António Craesbeck de Mello, 1677.

LANGE, Hermann. Vom Adel des doctor in: Das Profil des Juristen in der Europäischen Tradition. Symposion aus Anlaß des 70. Geburtstages von Franz Wieacker. Hg. von Klaus Luig und Detlef Liebs. Gremer: Ebelasbach, 1980. p. 279-294.

Römisches Recht im Mittelalter 1. Die Glossatoren. München, Beck, 1997.

; KRIECHBAUM, Maximiliane. Römisches Recht im Mittelalter. 2: Die Kommentatoren. München: Beck, 2007.

LEGENDRE, Pierre. L'empire de la vérité: introduction aux espaces dogmatiques industriels. Paris: Fayard, 1983. . Les enfants du texte. Paris : Fayard, 1993. . Surla question dogmatiqueen Occident. Paris: Fayard, 1999.

LEVACK, Brian P. The civil lawyers in England, 1603-1641: a political study. Oxford: Clarendon Press, 1973.

LOBO, Francisco Rodrigues Lobo. Corte de aldeia, arte de furtar, espelho de enganos, theatro de verdades, mostrador de horas minguadas, gazua geral dos Reynos de Portugal [...] Compostano anno de 1652 [...]. Amsterdã: Officina de Martinho Schagen, 1744. Disponível em: 〈http://purl.pt/21822〉. Acesso em: jan. 2017.

LUIG, Klaus. Richterköningtum und Kadijurisprudenz im Zeitalter von Naturrecht und Usus modernus: Augustin Leyser (16831752). Das Profil des Juristen in der europäischen Tradition. Symposion aus Anlaß des 70. Geburtstages von Franz Wieacker ., Hg. von Klaus Luig und Detlef Liebs. Gremer: Ebelasbach, 1980. 
MACEDO, António de Sousa de. Perfectus doctor, in quacunque scientia: maxime in jure canonico, \&e civili. Summorum autorum circinis, lineis, coloribus, \& $\&$ penicillis figuratus. Londini, [ex officina]: Richardi Hearn, [16]43. Disponível em: 〈http:/openlibrary.org/works/ OL7550080W/Perfectus doctor in quacunque_scientia_maxime_in_iure_canonico_civilì. Acesso em: fev. 2017.

. Armonia política dos documentos divinos com as conveniências do Estado. Haga, Samuel Broun Impressor Inglês, 1651.

MACHADO, Diogo Barbosa, Bibliotheca lusitana historica, critica e cronológica [...], Lisboa, A. J. Fonseca, 1741 (on line em https://books. google.pt/books?id=WJ3JdJ2XWioC\& $\&$ hl=pt-PT\& $\&$ source=gbs_similarbooks [ed. De 1752], consultado em Dez. 2017).

MARAVALL, José António. Poder, honrayélites en el siglo XVII. Madri: Siglo XXI, 2007 [1989].

MATIENZO, Juan de. Dialogus relatoris et advocati pintiani senatus in quo varia hinc inde porponuntur longe controvertuntur ad Renunciatorum, Advocatorum, iudicum Munera. Pintiae [Valladolid]: Loduvicus Sachez, 1653. Disponível em: shttp:// books.google.pt/books/about/Dialogus relatoris_et_aduocati_pintiani.html?id=08_oSIHyhc8C\&redir_esc=y.> Acesso em: jan. 2017.

MEDICK, Hans. "Missionare im Ruderboot"? Ethnologische Erkenntnisweisen als Herausforderung an die Sozialgeschichte. Geschichte und Gesellschaft, n. 10, p. 295-319, 1984 [Ed. fr., Genèses: Sciences Sociales et Histoire, n. 1, p. 24-46, 1990].

MEIKLE, Scott. Aristotle on Business. The Classical Quarterly, n. 46.1, p. 138-151, 1996.

MELO, Francisco Manuel de. Apólogos dialogais: primeiro. c. 1650. Disponível em: 〈http:/www. uc.pt/uid/celga/recursosonline/cecppc/textosempdf/llosrelogiosfalante . Acesso em: jan. 2017. Apólogos dialogais, apólogo dialogal segundo. Coimbra: Atlântida, 1962. p. 72-73.
Disponível em: 〈https://books.google.pt/ books?id=URhxSzKOEZoC\&pg=PA7l\&lp$\mathrm{g}=\mathrm{PA} 71 \& \mathrm{dq}=$ basta + que + um + homem + fale + confiado\&esource=bl\&tots=y73HLw2hFU\&si $\mathrm{g}=$ DvNNQ-37Xfb7RjDFrV99HCM2fCk\& $\mathrm{hl}=\mathrm{p}$ t-PT\&sa =X\&ved=0ahUKEYPSAhXh7oMKHSpbCtwQ6AEIIDAB \# $\mathrm{v}=$ =nepage\&eq $=$ basta $\% 20$ que $\% 20$ um $\% 2$ homem $\% 20$ fale $\% 20$ confiado\&ef=false>. Acesso em: abr. 2017.

MOFFA, Matteo Gribaldi. Demethodo acratione studendi. 154l. Disponível em: 〈https://play.google.com/store/books/details?id=HgMknWEYiskC\&rdid=book-HgMknWEYiskC\&rdot=1 [ed. 1544]’. Acesso em: jan. 2017.

MONTEIRO, Arlindo Camilo. O jurisperito de séc. XVII Des. Diogo Guerreiro Camacho de Aboim e o autor do Demetrio Moderno. Notula para a historia dos cultores do direito e das leis e sua critica em Portugal. Lisboa, 1940. Sep. de Petrus Nonius. OSSOLA, Carlo; PROSPERI, Adriano (Org.). La corte e il cortegiano. Bulzoni: Roma, 1980.

PAUL, $\mathrm{H}$. What is a scholarly persona? Ten theses on virtues, skills, and desires. History and Theory, n. 53, p. 348-371, 2014.

PEGAS, Manuel Álvares Pegas. Commentaria ad Ordinationes [...]. Ulyssipone, Variae, 1669$1703.14 \mathrm{v}$

PELORSON, Jean-Marc. Les letrados, juristes castillans sous Philippe III: recherches sur leur place dans la société, la culture et l'État. Poitiers: Université de Poitiers, 1980.

PEÑA Y MONTENEGRO, Alonso de la. Itinerario para Párrocos de Indios. Edición crítica por C. Baciero, M. Corrales, J. M. García Añoveros, F. Maseda. Madri: Consejo Superior de Investigaciones Científicas, 1995.

PEREIRA, Bento. Academia seures publicalitteraria. Ulyssipone: Antonio Craesbeck de Mello, 1662. Disponível em: https://play.google.com/ store/books/details?id=TXRZN5QWOlAC\&rdid=book-TXRZN5QWOlAC\&rdot=1>. Acesso em: fev. 2017. 
Pallas togata et armata documentis políticis in problemata humaniora digesta, Eborae 1636; Id., Academia seu respublica litteraria. Ulyssipone: Craesbeeck de Mello., 1662. Disponível em: 〈https://archive.org/details/ bub_gb_WNGlCIAr8VsC; https://play.google.com/store/books/details/Bento_Pereyra Academia_seu_respublica_litteraria_v?id=LMaKG OmNÜC). Acesso em: mar. 2017.

PEREYRA, Juan Solórzano Pereyra.Políticaindiana: Libro primero. Libro segundo. Madri: Fundación José Antonio de Castro, 1996. Disponível em: 〈https://play.google.com/store/books/details?id=bMRQAAAAcAAj\& rdid=book-bMRQAAAAcAAJ\&erdot=1>. Acesso em: mar. 2017.

PETIT, Carlos. Oralidad y escritura, o la agonia del metodo en el taller del jurista histotiador. In: Historia. Instituciones. Documentos, n. 19, p. 327-380, 1992. Disponível em: 〈http://institucional.us.es/revistas/historia/19/20\%20 petit\%20calvo.pdf . Acesso em: fev. 2017.

Discurso sobre el discurso: oralidad y escritura en la cultura jurídica de la España liberal. Madri: Universidad Carlos III, 2014. Disponível em: 〈http://e-archivo.uc3m.es/bitstream/handle/10016/19670/discurso_petit_hd30_2014. pdf? sequence=3.> . Acesso em: mar. 2017.

PORTO, Rodrigo do. Manual de confessores e penite [n] tes em ho qual breue \& particular \& muy verdadeyramente se decidem e declarã quasi todas as duuidas e casos que nas confissões soe [m] occorrer acerca dos peccados, absoluições, restituyções é censuras/composto por hu $[\mathrm{m}]$ religioso da ordem de Sam Francisco da prouinciada piedade [...]. Coimbra: Ioã da Barreyra \&e Ioã Aluares, 1549. Disponível em: 〈http://purl.pt/14308〉. Acesso em: jan. 2017. PREST, Leonard William. Lawyersinearlymodem Europe and America. Londres-New York, Croom Helm- Holmes and Meister Publishers, 1981.

PRESTAGE, Edgar. O Conselho de Estado. Dom João IV e dona Luísa de Gusmão. Lisboa, Arquivo Histórico Português, 1919.
RANIERI, Filippo. Juristiche Literatur aus dem Ancien Régime und historische Literatursoziologie. Eine methodologische Vorüberlegungen. In: Aspekte europäischer Rechtsgeschichte. Festgabe für Helmut Coimg zum 70. Geburtstag. Frankfurt/Main: V. Klostermann,1982. Vom Stand zum Beruf. Die Professionalisierung des Juristenstandes als Forschungsaufgabe der europäischce Rechtsgeschichte der Neuzeit. Ius Commune, n. 13, p. 83-105, 1985 [Em inglês: From status to profession: the professionalisation of lawyers as a research field in modern European legal history. Journal of Legal History, n. 10, p. 180190, 1989; em português: A profissionalização do corpo de juristas como objecto de estudo da história do direito europeu da época moderna. Penélope. Fazer edesfzer a história, 1, p. 41-63, 1988]. Elestilojudicial español y su influencia en la Europa del Antiguo Régimen. In: MARTÍN, Antonio Pérez. Españay Europa, un pasado jurídico común. In: I SIMPOSIO INTERNACIONAL DEL INSTITUTO DE DERECHO COMÚN. Anais... Murcia, 1986. p. 101-118. Disponível em: 〈https://books.google.pt/books?id=psdhzlwxcCoC\&epg=PAlll\&elpg=PAll1\&dq=Motiva+sunt+pars+sententiae.+Urteilsbegr\%C3\%BCndung\&\&source=bl\&ots=M9lVUz9l16\&esig=5_C6-wYtuM7zyt6ltdqZI38xp$0 \&$ hl=pt-PT\&sa=X\&ei=OqsiVfeKKsH4UrX_ g7gI\&ved=0CCsQ6AEwAg\# Motiva\%20sunt $\% 20$ pars\%20sententiae.\%20 Urteilsbegr $\%$ C3\%BCndung\& $\mathrm{Ef}=\mathrm{false}>$. Acesso em: mar. 2017.

ROVITO, Pier Luigi. Respublica dei togati: giuristi e societa nella Napoli del Seicento. Nápoles: Jovene, 1981.

SARTI, Mauro et al. Declaris Archigymnasii bononiensis professoribus a saeculo XI usque ad saeculum XIV. Bononiae: Merlani, 1888. Disponível em: 〈http://www.archive.org/details/declarisarchigyOlalbigoog; http://books.google.com/ebooks/ reader?id=02vT2cxyCf8C\& \&hl=pt-PT\& $\mathrm{sec}=$ frontcover\&output=reader . 
SAVIGNY, Friedrich Karl von. Geschichte des römischen Rechts im Mittelalter. Heidelberg, Mohr und Zimmer 1831. Disponível em: 〈https://play.google.com/store/books/details/ Friedrich_Karl_von_Savigny_Geschichte des r\%C3\%B6mische?id=PkUUAAAAQAAJ). [Trad. franc.: Histoire du droit romain au Moyen Age. Paris, Charles Ingray, 1839. Disponível em: 〈https://books.google.pt/ books/reader?id=q4QDAAAAQAAJ\& $\mathrm{hl}=\mathrm{p}$ $t$-PT\& $\&$ printsec $=$ frontcover\&output=reader\&pg $=$ GBS.PP15>].

SBRICCOLI, Mario. L'interpretazione delloStatuto: contributo allo studio della funzione dei giuristinell'età comunale. Milão: Giuffrè, 1969.

. Politique et interprétation juridique dans les villes italiennes du Moyen-Âge. Archives de Philosophie du Droit, n. XVII, p. 99-113, 1972. SCHIAVONE, Aldo. Ius. L'invenzione del diritto in Occidente. Bari: Einaudi, 2005.

SCHMÖLDERS, Claudia. Das Gesicht des Angeklagten. Uber physiognomisches (Ver) Urteilen. Rechtshistorisches Journal, n. 15, p. 206-236, 1996.

SCHOLZ, Johannes-Michael. Motiva sunt pars sententiae. Urteilsbegründung in Aragon (16.18. Jahrhundert). In: PARADISI, Bruno (Org.). La formazione storica del diritto moderno in Europa. Firenze: Olschki, 1977. v. II, p. 581-598.

SOTO, Domingo de. De iustitia et de iure. Salamanca: Andreas Portonarijs, 1556; Madri: Instituto de Estudios Políticos, 1968.

STAMMEN, Theo (Dir.) et al. PolitikBildung - Religion. Hans Maier zum 65. Geburtstag, Paderborn u. a., 1996.STOLLEIS, Michael. Juristenbeschimpfung, oder: Juristen — böse Christen. In:

SUBTIL, José. Dicionário dos desembargadores (1640-1834). Lisboa: Ediual, 2010.

TESTUZZA, Maria Sole. "Ius corporis, quasi ius de corpore disponendi": il Tractatus de potestate in se ipso di Baltasar Gómez de Amescua. Milão: Giuffrè, 2016.

THOMPSON, Edward P. Customs in common. Nova York: New Press, 1991.

VALLAURI, Luigi Lombardi. Saggio sul diritto giurisprudenziale. Milão: Giuffrè, 1967.

VASCONCELOS, Jorge Ferreira de. Comedia eufrosina. Coimbra: João de Barreira, 1555. Disponível em: 〈http://purl.pt/594l/6/f-6220 PDF/f-6220 PDF 01-B-R0150/f-62200000 rosto-315 t01-B-R0150.pdf> [Ed. moderna consultada: Aubrey F. Bell. Lisboa: Imprensa Nscional, 1915. Disponível em: 〈https:// archive.org/stream/comdiaeufrosin00vascuoft/comdiaeufrosin00vascuoft djvu.txt?. Acesso em: jan. 2017].

VELASCO, Gabriel Alvarez de. Iudexperfectus seu de iudice perfecto Christo Iesu Domino nostro vnice perfecto [...]. Lugduni: Horatii Boissat $\&$ Georgii Remeus, 1662. Disponível em: 〈https://play.google.com/store/books/details?id=hY9wps3q6sUC\&rdid=book-hY9wps3q6sUC\&rdot=17. Acesso em: mar. 2017.

- Judex perfectus seu de judice perfecto Christo Iesu. Lausonii et Colinae Allobrogum, 1740. Disponível em: 〈http://books.google. pt/books/about/Iudex perfectus.html?i-

$\mathrm{d}=\mathrm{h} 3 \mathrm{xEAAAAcAAJ \& redir}$ esc $=\mathrm{y}\rangle$. Acesso em: mar. 2017.

VIEHWEG, Theodor. Topik und. Jurisprudenz. München: Beck, 1953.

VILLEY, Michel. La formation de la pensée juridique moderne: cours d'histoire de la philosophie du droit, 1961-1966. Paris: Montchrestien, 1968.

VOLPINI, Paola. Lo spazio politico del "letrado": Juan Bautista Larrea magistrato e giurista nella monarchia di Filippo IV. Bolonha: Il Mulino, 2004.

ZYMA, Peter. Textsoziologie: Eine kritische Einführung. Stuttgart: Metzler, 1980. 